\title{
EFFECT OF THE CONSUMPTION OF A FOOD BASED ON FRUITS AND NATURAL ADDITIVES IN PATIENTS WITH CARDIOVASCULAR RISK
}

\author{
EFECTO DEL CONSUMO DE UN ALIMENTO CON BASE DE FRUTAS Y ADITIVOS \\ NATURALES EN PACIENTES CON RIESGO CARDIOVASCULAR
}

\author{
María Camila FRANCO LONDOÑO, MSc ${ }^{1 *}$; Adrián ISAZA, $\mathrm{MD}^{2}$; Gladys POSADA³ ; María Elena \\ MALDONADO CELIS, $\mathrm{PhD}^{3}$
}

Received: June 22 of 2018. Approved: July 30 of 2019.

\begin{abstract}
Background: cardiovascular diseases (CVD), a group of disorders of the heart and blood vessels are the main cause of morbidity and mortality worldwide. Strategies for its prevention have been proposed, such as modifying life habits, including increasing the consumption of fruits and vegetables associated with the decrease in the probability of suffering CVD. Objective: to evaluate the effects of a base compote of guava (Psidium guajava) and passion fruit (Passiflora ligularis) on blood pressure and metabolic and inflammatory biomarkers in hypertensive type two diabetic patients. Methods: food characterization test (microbiological, proximal, sensorial, antioxidant activity and total phenols). The compote was administered for 21 days to 8 adults (30 to 65 years old); glycaemia, blood pressure, inflammatory markers, and BMI and waist circumference before and after the intervention were measured. Results: the sensory test showed: $66 \%$ acceptance and all attributes a value $>3$, indicating that it was well evaluated. The microbiological aspects comply with the safety for human consumption and nutritionally it stands out that the contribution of carbohydrates $(12.3 \%)$ is adequate for these patients. The hydrophilic ORAC value was $98.570 \mu \mathrm{mol} \mathrm{ET/g}$ sample. In the patients at the end of the study, a statistically significant decrease in systolic blood pressure was observed $(127 \mathrm{mmHg}, \mathrm{p} 0.041)$ and the pro-inflammatory markers TNF $\alpha$, IL-1 $\beta$ and IL6 $(31.9 \mathrm{pg} / \mathrm{mL}, \mathrm{p} 0.012,31.9 \mathrm{pg} / \mathrm{mL}, \mathrm{p} 0.012$, and $3.5 \mathrm{pg} / \mathrm{mL}, \mathrm{p} 0.017$ respectively) and glycaemia increase $(157.5 \mathrm{mg} / \mathrm{dL}, \mathrm{p}$ 0.036). Conclusions: the medium-term consumption of a compote based on guava, passion fruit, cinnamon and flaxseed oil improves systolic blood pressure and the proinflammatory markers TNF $\alpha$, IL-1 $\beta$ and IL6 in diabetic and hypertensive patients.
\end{abstract}

Keywords: cardiovascular risk, functional foods, tropical fruits, phenolic compounds.

\section{RESUMEN}

Antecedentes: las enfermedades cardiovasculares (ECV), conjunto de trastornos del corazón y los vasos sanguíneos son la principal causa de morbilidad y mortalidad en todo el mundo. Se han propuesto estrategias para su prevención como modificar los hábitos de vida, incluyendo aumentar el consumo de frutas y verduras asociadas con la disminución en la probabilidad de sufrir ECV. Objetivo: evaluar los

\footnotetext{
Magister in Pharmaceutical and Food Sciences, Universidad de Antioquia. Medellín, Colombia.

Professor Galen College Florida, USA.

Professor School of Nutrition and Dietetics, Universidad de Antioquia, Medellín, Colombia.

Corresponding author: nutricionistacamilafranco@gmail.com
} 
efectos de una compota base de guayaba (Psidium guajava) y granadilla (Passiflora ligularis) en la presión arterial y biomarcadores metabólicos e inflamatorios en pacientes diabéticos tipo 2 hipertensos. Métodos: caracterización del alimento prueba (análisis microbiológico, proximal, sensorial, actividad antioxidante y fenoles totales). Se suministró la compota durante 21 días a 8 adultos (30 a 65 años), se midió glicemia, presión arterial, marcadores inflamatorios, IMC y perímetro de cintura antes y después de la intervención. Resultados: la prueba sensorial mostró: $66 \%$ de aceptación, y todos los atributos un valor $>3$, indicando que fue bien evaluado. Los aspectos microbiológicos cumplen con la inocuidad para consumo humano y nutricionalmente se destaca que el aporte de carbohidratos (12,3\%) es adecuado para estos pacientes. El valor ORAC hidrofílico fue $98,570 \mu \mathrm{mol}$ ET/g muestra. En los pacientes al final del estudio se observó disminución estadísticamente significativa de la presión arterial sistólica $(127 \mathrm{~mm} \mathrm{Hg}$; p 0,041) y los marcadores proinflamatorios TNF $\alpha$, IL-1 $1 \beta$ e IL6 $(31,9$ pg/mL, p 0,012; 31,9 pg/mL, p 0,012; y 3,5 pg/ $\mathrm{mL}, \mathrm{p}$ 0,017, respectivamente) e incremento de la glicemia (157,5 mg/dL, p 0,036). Conclusión: el consumo a mediano plazo de una compota a base de guayaba, granadilla, canela y aceite de linaza mejora la presión arterial sistólica y los marcadores pro inflamatorios TNF $\alpha$, IL-1 $\beta$ e IL6 en pacientes diabéticos e hipertensos.

Palabras clave: riesgo cardiovascular, alimentos funcionales, frutas tropicales, compuestos fenólicos.

\section{INTRODUCTION}

Cardiovascular diseases are a group of disorders of the heart and blood vessels. Currently, they are the main cause of morbidity and mortality worldwide, each year more people die from CVD (cerebrovascular disease) than from any other cause (1). More than three quarters of CVD deaths occur in low and middle-income countries (2). However, $80 \%$ of myocardial infarctions and of premature stroke (cerebrovascular accidents) are preventable (3). To improve cardiovascular health, it is necessary to promote healthy lifestyles, that is, to act on behavioral risk factors, such as tobacco consumption, unhealthy diets, obesity, physical inactivity and alcohol consumption (4).

People with CVD or high cardiovascular risk, such as high blood pressure, diabetes, hyperlipidemia, are focal groups of early treatment, to avoid further complications, since it has been demonstrated that the modification of behavioral risks reduces the risk of CVD (1). In 2013, 194 countries agreed, under the leadership of WHO (world health organization), the "Global Plan of Action for the Prevention and Control of NCDs (Non-communicable Diseases) 2013-2020". The purpose of the aforementioned plan is to reduce the number of premature deaths associated with NCDs by $25 \%$ by 2025 , by means of nine global targets of voluntary application. Two of these global goals focus directly on the prevention and control of CVDs.
The concept of inflammation is decisive in the pathophysiology of CVD, among these hypertension. The inflammatory process in the blood vessels is the result of chemotaxis and the participation of a set of hematological cells and the vascular wall expressed in forms of intercellular (ICAM-1) and vascular (VCAM1) adhesion molecules that give rise to the adhesion of monocytes to the vascular wall and their extravasation towards the interstitial space and the formation of a cell set of macrophages, neutrophils, basophils, primed cells, and eosinophils (5). At the same time, on the intravascular endothelial surface there is the activation of a state of platelet adhesiveness and the formation of fibrin networks that lead to a prothrombotic state. Inflammation is the result of immune reactions and the expression of vasoconstrictor systems such as the renin-angiotensin system. In clinical studies of arterial hypertension, some techniques have been designed that measure the markers of systemic inflammation, whose measurement allows to deepen the knowledge of the pathophysiology of arterial hypertension and to know the level of related cardiovascular risk of arterial hypertension and measure the evolution of the hypertensive state. They are considered as the main markers of systemic inflammation in hypertension to various cytokines, especially interleukin-6 (IL-6) and certain acute phase reagents of inflammation such as C-reactive protein (6). 
Among the causes of endothelial dysfunction, there are risk factors previously described cardiovascular and hemodynamic factors, as it is known that the endothelium has major lesions in places where there is more blood flow (6). Once the leukocytes have adhered to the wall vascular, its entrance to the interior is controlled by chemokines, such as interleukins IL1, IL 6 and PCR (C-reactive protein); so the latter have been considered two cardiovascular risk markers.

The consumption of fruits and vegetables has been shown to contribute to the prevention of CVD, due to its contribution of phenolic compounds, which offer protection against the consequences of oxidative stress through the regulation of inflammatory mediators, likewise, improve glucose homeostasis and they favor vasodilation, which has effects on vascular function (7-9). The purpose of this study was to evaluate the effects of a base compote of guava (Psidium guajava) and passion fruit (Passiflora ligularis) on blood pressure and metabolic, inflammatory and antioxidant biomarkers of type 2 hypertensive diabetic patients.

\section{MATERIALS AND METHODS}

\section{Sample food}

One serving contained $100 \mathrm{~g}$ of compote, made with ripe pink guava (Psidium guajava L) $(50 \mathrm{~g}$ without seeds), passion fruit pulp (Passiflora ligularis Juss) (30 g), linseed oil (the Vitamin Shoppe ${ }^{\circledR}$ Specialty, USA) (5 g), cinnamon powder ( $2 \mathrm{~g})$ and $13 \mathrm{~mL}$ of water. The vegetable inputs were acquired in local markets according to the Colombian technical standards for the fruits described $(8,9)$. The compote was stored under refrigeration at $4^{\circ} \mathrm{C}$ preserving its cold chain.

A previous study showed that the consumption of $500 \mathrm{~mL}$ a smoothie prepared with guava and granadilla exhibited a cardiovascular protective effect by reducing systolic and diastolic blood pressure in hypertensive patients with DM2. However, the antioxidant and the parameters blood associated with DM2 weren't analyzed. Based on these results, the author suggested that the daily consumption of this shake may have a long-term effect on blood pressure in diabetic patients, which leads to the formulation of this project to determine if there is a long-term effect on the clinical variables associated with HTA and DM2 (10). It was wanted to observe if in a regular portion size for this type of preparation (compote) and with medium-term consumption, beneficial effects could be observed.

Colombia has great biodiversity in its fauna and flora, its varied climate has allowed obtaining a variety of fruits and vegetables during all months of the year. Likewise, has recently increased the interest in knowing the health properties of different tropical fruits such as mango, pineapple, Cape gooseberry, passion fruit (passion fruit, curuba, and granadilla) and guava. The last two are of interest in our research project due to the potential health benefits attributed to its fiber content and antioxidant capacity attributed to its phenolic compounds $(11,12)$. Flaxseed oil was used to obtain a contribution of omega 3 and cinnamon with a double purpose, to enhance the sweet taste of fruits, in addition to its contribution of cinnamaldehyde other compounds with antiinflammatory activity (13).

\section{Antioxidant activity}

It was analyzed by the ORAC method (14) that measures the stabilizing effect of the free radicals that the antioxidant compounds have by means of a mechanism of donation of a hydrogen atom. In this method, the artificial radical AAPH (2,2'-Azobis(2-aminopropane dihydrochloride) generates peroxide radicals (ROO) that oxidize fluorescein so that fluorescein loses its fluorescence. the indicator of the extent of oxidation with peroxide radical, the presence of antioxidants in the medium decreases the loss of fluorescence, therefore, monitoring the kinetics of oxidative degradation of fluorescein (area under the curve) to a excitation and emission wavelengths of 485 and $520 \mathrm{~nm}$ respectively, in the presence of a standard antioxidant such as Trolox (alpha tocopherol hydrophilic analog) allows to establish the protective effect of fluorescein oxidation over time for increasing concentrations of the standard and in front of a particular sample. For the hydrophilic ORAC, approximately 100 mg were weighed in triplicate of the sample, an extraction of 45 minutes by sonication with a basic ethanol-water extracting solution, the obtained extract was normalized in a volume of $2 \mathrm{~mL}$ with extracting solution; subsequently dilution 1 in 200 was made in phosphate buffer. For the lipophilic ORAC, approximately $300 \mathrm{mg}$ of the sample was weighed in triplicate, then 50 minutes extraction was performed by sonication using acetone as 
extractor solvent, the obtained extract was taken to $2 \mathrm{~mL}$ volumetric flask and gauging with acetone; subsequently, 1 in 50 dilutions was performed in 7\% cyclodextrin (acetone-water, 50:50). The quantitative analysis was performed by the external standard method and for this a calibration curve was established with different concentrations of Trolox, expressing the results in terms of $\mu \mathrm{mol}$ of Trolox equivalents per gram of sample $(\mu \mathrm{mol} \mathrm{ET/g}$ of sample).

\section{Determination of total phenols}

Polyphenols are determined colorimetrically using the Folin Ciocalteu reagent (11). The reagent contains phosphotungstic acid as oxidant, which in an alkaline medium is easily reduced by phenolic groups producing a blue color with a maximum absorbance at $765 \mathrm{~nm}$, quantified spectrophotometrically based on a calibration curve using gallic acid as a reference standard. Approximately $100 \mathrm{mg}$ were weighed in triplicate from the sample, an extraction of 45 minutes was performed per sonication with a basic ethanol-water extraction solution, and the extract obtained was normalized in a volume of $2 \mathrm{~mL}$ with extracting solution. Subsequently, the following dilution was carried out 1 in 20 in type II water. The quantitative analysis was performed by the external standard method and for this a calibration curve was established with different concentrations of gallic acid, expressing the results in terms of $\mathrm{mg}$ equivalents of gallic acid per gram of sample (mg EAG/g sample).

\section{Proximate analysis}

The standard protocols stipulated by (ICONTEC) and the Official Association of Analytical Chemists (AOAC) (15) methods per $100 \mathrm{~mL}$ of food were carried out. Parameters were determined as humidity (loss by drying) according to the Colombian Technical Guide (GTC) 1.14; total fat according to GTC 6.1; total ash following AOAC 923.03, total protein, according to AOAC 954.01; total nitrogen according to AOAC 954.01 micro Kjeldhal method, carbohydrates and total calories, from the components.

\section{Microbiological analysis}

Was performed according to the NTC 285 (16) which includes count of mesophylls according to INVIMA, count of coliforms, Escherichia coli, mold and yeasts in accordance with NTC 4458 horizontal method, Clostridium sulfite reducing spore was also counted by tube count according to the procedure described by INVIMA and Salmonella species was carried out by horizontal method according to ISO 6579 .

\section{Sensory analysis}

An acceptance and affective test was carried out evaluating the level of liking with a hedonic scale of 5 points: I like it a lot, I like it lightly, I do not like it or dislike it, I dislike it slightly and dislike me, for the attributes color, smell, taste, sweetness and consistency. One hundred untrained panelists of both genders evaluated the product.

\section{Subjects}

A total of 8 adults (30 to 65 years old) men and women diagnosed with hypertension and diabetes mellitus (Blood pressure (BP) $\geq 130 / 80$, fasting glucose $\geq 126 \mathrm{mg} / \mathrm{dL}$ ) with a diagnosis of at least 1 year, were recruited in the city of Medellín through e-mail and notices sent. The patients controlled their diabetes with oral hypoglycemic agents. Patients were excluded from the study if they smoked, had endocrine, liver, kidney or cardiovascular diseases diagnosed, gastrointestinal disease, psychological illness, eating disorders, pregnancy, lactation, asthma and allergies, consumption of supplements and use of insulin. The study was carried out in accordance with the guidelines established in the Declaration of Helsinki and the Ethics Committee of the Center approved all procedures involving human beings for Pharmaceutical Research (CECIF). All participants signed written informed consent. The subjects were warned not to change their dietary habits, physical activities or medication. The dietary intakes of the subjects were evaluated using a simple consumption frequency.

\section{Study design}

This was a quasi-experimental study. The small sample size and the duration (medium term) correspond to a pilot test, where we wanted to validate the consumption of this functional food prototype in people with specific risk factors. At the beginning and at the end of the intervention period (21 days), the subjects were asked to come after $12 \mathrm{~h}$ of nightly fasting to provide a blood sample, measure BP (blood pressure) and calculate the body mass index. The participants' compliance 
of less than $80 \%$ served as a reason to be withdrawn from the study. Each participant consumed 100 grams of compote on an empty stomach for 21 days. This was stored under refrigeration $\left(4^{\circ} \mathrm{C}\right)$ during the intervention period.

\section{Obtaining blood samples and analysis}

Blood samples were collected after an overnight fast at the beginning and end of the study in heparinized tubes and were stored at $-20^{\circ} \mathrm{C}$ until analysis. The serum concentration of glucose, lipid profile, IL-1 $\beta$, TNF- $\alpha$, IL-6, and C-reactive protein were measured using commercial kits and following the manufacturer's instructions.

\section{Clinical history and anthropometric analysis and blood pressure}

The medical history was collected and analyzed by a physician; this included personal, pharmacological, family, toxicological and physical activity history. A complete physical examination and determination of anthropometric measures according to standardized methods was also carried out. The subjects were weighed and measured before and after the intervention. All the measurements were carried out with the participants fasting and wearing light clothes. The weight was determined with a scale, in standing position; the value obtained approached the nearest $0.1 \mathrm{~kg}$. The size was measured using a tape measure with the patient straight back against the wall; the abdominal perimeter was measured twice in each standing position with the arms at the sides, using a standardized tape measure, applied horizontally in a midpoint between the iliac crest and the costal margin. The body mass index (BMI) was calculated using the formula weight/ height ${ }^{2}$. It evaluated or systemic blood pressure by using a sphygmomanometer of mercury twice in the right arm, spaced each measurement for five minutes, with the patient sitting comfortably after five minutes of rest, systolic and diastolic blood pressure were taken with the first and fifth noise of Korotkoff respectively.

\section{Statistical analysis}

Non-parametric statistics analyzes were performed given the sample size. The Wilcoxon test was applied to establish the significance of the differences between the samples before and after the supplementation. The data was analyzed in the
SPSSP software. Values of $\mathrm{p}<0.05$ were considered statistically significant.

\section{RESULTS}

\section{Sample food}

\section{Microbiological analysis}

The microbiological results obtained from the sample are in accordance with those established by NTC 285 for processed fruits, jams and fruit jellies (16). Therefore, it is considered that the preparation conditions are suitable and the test food is safe for human consumption (Table 1). Proximal analysis: according to the results presented in Table 1, the test food presented nutritional properties that make it suitable to be included in the feeding plan for people with diabetes due to their moderate intake of carbohydrates and calories, with a high intake of moisture, according to the composition of the main ingredients and is low glycemic index (17).

Table 1. Proximate and microbiological analysis of the compote.

\begin{tabular}{|c|c|c|}
\hline Parameter & \multicolumn{2}{|c|}{ Value } \\
\hline Moisture & \multicolumn{2}{|r|}{85.56} \\
\hline Total protein ${ }^{1}$ & \multicolumn{2}{|r|}{1.26} \\
\hline Total carbohydrates $^{1}$ & \multicolumn{2}{|r|}{12.18} \\
\hline Total fats ${ }^{1}$ & \multicolumn{2}{|r|}{0.48} \\
\hline Total ashes $^{1}$ & \multicolumn{2}{|r|}{0.41} \\
\hline Calories $^{2}$ & \multicolumn{2}{|r|}{58.51} \\
\hline${ }^{\circ}$ Brix & \multicolumn{2}{|c|}{$8.8 \pm 0.13$} \\
\hline $\mathrm{pH}$ & \multicolumn{2}{|c|}{$4.03 \pm 0.02$} \\
\hline \multicolumn{3}{|l|}{ Microbiological analysis } \\
\hline Parameter & Result & Reference Value \\
\hline Mesophile count ${ }^{3}$ & $<100$ UFC & $<100$ UFC \\
\hline Coliform Count $^{3}$ & $<10$ UFC & $<10 \mathrm{UFC}$ \\
\hline Escherichia coli Count ${ }^{3}$ & $<10$ UFC & $<10$ UFC \\
\hline Mold and yeast count ${ }^{3}$ & $<100$ UFC & 300 UFC \\
\hline $\begin{array}{l}\text { Clostridium sulfite reducing } \\
\text { sporea count }{ }^{3}\end{array}$ & $<10$ UFC & $<10 \mathrm{UFC}$ \\
\hline Salmonella sp. & Absence & Absence \\
\hline
\end{tabular}

${ }^{1} \mathrm{~m} / \mathrm{m} ;{ }^{2} \mathrm{Kcal} / 100 \mathrm{~g} ;{ }^{3} \mathrm{UCF} / \mathrm{g}$ o mL; UFC: colony forming unit.

\section{Analysis of antioxidants and total phenols}

The content of total phenols, as well as that of antioxidant activity, hydrophilic and lipophilic phase ORAC are presented in Table 2, both methods being the most used for food matrices. 
Table 2. Total phenol content and antioxidant activity of the compote.

\begin{tabular}{|l|c|c|}
\hline \multicolumn{1}{|c|}{ Parameter } & Average \pm Standard Deviation (SD) & RSD (\%) \\
\hline Total phenols $^{1}$ & $2.31 \pm 0.124$ & 5.35 \\
\hline Hydrophilic ORAC $^{2}$ & $98.57 \pm 1.500$ & 1.52 \\
\hline Lipophilic ORAC $^{2}$ & $31.77 \pm 2.01$ & 6.34 \\
\hline
\end{tabular}

Samples were analyzed in triplicate. RSD: Coefficient of variation, preferably it must be less than $10 \% .1 \mathrm{mg}$ EAG/g sample: ${ }^{1}$ milligrams equivalent of gallic Acid. ${ }^{2} \mu \mathrm{mol}$ ET: equivalent micromols of Trolox/g sample.

\section{Sensory analysis test}

The compote had a $66 \%$ acceptance in the general public. The acceptance was observed regarding its sensory characteristics because the scores for the sensory attributes odor (4.2), taste (3.3), sweetness (3.1) and consistency (3.9) were higher than 3 , on a scale of 1 to 5 .

It should be noted that the compote was evaluated by the general public, which usually uses this type of food with the addition of sweeteners (sugar or others). Therefore, it was considered to be in an acceptable range of acceptance, because this formulation had no sweetener and its flavor was natural fruit.

Table 3. Characterization of study participants (dietary analysis, comorbidities and physical activity).

\begin{tabular}{|c|c|c|c|}
\hline \multicolumn{4}{|c|}{ Dietary Analysis } \\
\hline Variable & Media \pm SD & Mediana (IR) & Min - Max \\
\hline Fruits and vegetables ${ }^{1}$ & $2.8 \pm 2$ & $3(1-4.5)$ & $0-5$ \\
\hline Milk and derivates & $1.1 \pm 1$ & $1(1-1)$ & $0-3$ \\
\hline Meats & $1.1 \pm 1$ & $1(1-1.5)$ & $0-2$ \\
\hline Complex carbhohydrates & $4.6 \pm 1$ & $4.5(4-5)$ & $4-6$ \\
\hline Simple carbohydrates & $2.1 \pm 2$ & $2(0-4)$ & $0-5$ \\
\hline Saturated fat & $1.6 \pm 1$ & $1.5(1-2)$ & $1-3$ \\
\hline Unsaturated fat & $2.1 \pm 2$ & $2.5(0-3.5)$ & $0-5$ \\
\hline High sodium products & 0 & 0 & $0-1$ \\
\hline \multicolumn{4}{|c|}{ Other variables } \\
\hline & & & $\%$ \\
\hline \multirow[b]{2}{*}{ Comorbidity } & \multicolumn{2}{|r|}{ Yes } & 75.0 \\
\hline & \multicolumn{2}{|r|}{ No } & 25.0 \\
\hline \multirow{3}{*}{ Physical activity } & \multirow[b]{2}{*}{ Yes } & $<30$ minutes/week & 25.0 \\
\hline & & $\begin{array}{l}\text { Between } 30 \text { and } 150 \\
\text { minutes/ week }\end{array}$ & 37.5 \\
\hline & \multicolumn{2}{|r|}{ No } & 37.5 \\
\hline
\end{tabular}

SD: Standard Deviation; ${ }^{1}$ Number of servings consumed per day, established according to food exchange list (18); IR: interquartile range.

\section{Characterization of the subjects}

The analyzed subjects had between 30 a 65 years. The dietary analysis was carried out through a simple semi-quantitative survey, in which they reported the monthly, weekly and daily consumption of different food groups. It was found that on average they consumed between 2.8 servings of fruits and vegetables, 1.1 of dairy products and meats, 4.6 of complex carbohydrates, 2.1 of simple carbohydrates, 1.6 of saturated fats and consumption of high-sodium foods was weekly. Seventy-five \% had comorbidities, the most common being dyslipidemia. With regard to physical activity, 25\% performed less than 30 minutes a week, $37.5 \%$ between 30 and 150 minutes, all were low intensity activities (Table 3 ). 
Effect on the anthropometric, blood pressure, biochemical and pro-inflammatory variables

Table 4 presents the results obtained in the participants after 21 days of consuming the compote compared with its baseline state, that is, at the beginning of the intervention (day 1). A tendency to decrease in weight and BMI was observed, however, this decrease was not statistically significant. In relation to blood pressure there was a decrease in both systolic blood pressure (SBP) in both diastolic blood pressure, however, only SBP was significant ( $p$ 0.041). For the lipid profile, although no significant changes were found, there is a tendency to decrease for the evaluated parameters (total cholesterol, triglycerides, LDL, VLDL and HDL). As for the levels of fasting glucose in blood, a significant increase was observed (p 0.036), but not for glycosylated hemoglobin that reflects the average of glycaemia during the previous 2-3 months. Regarding pro-inflammatory markers, a statistically significant decrease was observed in the cytokines evaluated: TNF $\alpha$ (p 0.012), IL1 $\beta$ (p 0.012 ) and IL6 ( $p$ 0.017). A tendency to decrease CRP was observed, but it did not present statistical significance.

Table 4. Effect of the consumption of the compote of guava, granadilla, linseed oil and cinnamon on the biochemical, anthropometric parameters and the blood pressure of the participants.

\begin{tabular}{|c|c|c|c|c|c|}
\hline \multirow{2}{*}{ Variables } & \multicolumn{2}{|c|}{ Day 1 of Intervention } & \multicolumn{3}{|c|}{ Day 21 of Intervention } \\
\hline & Median (RI) & Min - Max & Median (IR) & Median (RI) & P value \\
\hline Weight (Kg) & $\begin{array}{c}70.1 \\
(63.8-92) \\
\end{array}$ & $61-109.5$ & $\begin{array}{c}69.3 \\
(63.7-90.4) \\
\end{array}$ & $60-110$ & 0.141 \\
\hline BMI $\left(\mathrm{kg} / \mathrm{m}^{2}\right)$ & $\begin{array}{c}31.9 \\
(25.4-37.9) \\
\end{array}$ & $21.6-45.3$ & $\begin{array}{c}31.5 \\
(25.4-37.8) \\
\end{array}$ & $21.3-44.5$ & 0.123 \\
\hline $\begin{array}{l}\text { Waist } \\
\text { Circumference (cm) }\end{array}$ & $\begin{array}{c}96.5 \\
(93.2-113.4)\end{array}$ & $88.3-126$ & $\begin{array}{c}96 \\
(89.6-112)\end{array}$ & $88.5-122$ & 0.069 \\
\hline $\mathrm{SBP}(\mathrm{mmHg})$ & $129(110-137)$ & $108-148$ & $\begin{array}{c}127 \\
(109-129) \\
\end{array}$ & $106-138$ & 0.041 \\
\hline DBP (mmHg) & $\begin{array}{c}79 \\
(70-89)\end{array}$ & $70-92$ & $76(71-85)$ & $70-90$ & 0.102 \\
\hline CRP (md/dL) & $\begin{array}{c}0.4 \\
(0.2-0.8) \\
\end{array}$ & $0.1-3$ & $\begin{array}{c}0.3 \\
(0.1-0.5) \\
\end{array}$ & $0.1-0.9$ & 0.176 \\
\hline Cholesterol total (md/dL) & $\begin{array}{c}196 \\
(178-244.5) \\
\end{array}$ & $142-319$ & $\begin{array}{c}195.5 \\
(167.5-261) \\
\end{array}$ & $154-342$ & 0.327 \\
\hline Triglycerides (md/dL) & $\begin{array}{c}145.5 \\
(85.5-207) \\
\end{array}$ & $49-635$ & $\begin{array}{c}137 \\
(101-276) \\
\end{array}$ & $64-886$ & 0.069 \\
\hline HDL (md/dL) & $\begin{array}{c}52.7 \\
(35.8-69.4) \\
\end{array}$ & $30.8-74.6$ & $\begin{array}{c}50 \\
(32.6-69.6) \\
\end{array}$ & $26-78.2$ & 0.483 \\
\hline $\mathrm{LDL}(\mathrm{md} / \mathrm{dL})$ & $\begin{array}{c}106.3 \\
(80.2-127.2) \\
\end{array}$ & $61.2-241.4$ & $\begin{array}{c}97.6 \\
(85.3-119) \\
\end{array}$ & $69.4-253$ & 1.000 \\
\hline VLDL (md/dL) & $\begin{array}{c}29.1 \\
(17.1-41.4) \\
\end{array}$ & $9.8-127$ & $\begin{array}{c}27.4 \\
(20.2-55.2) \\
\end{array}$ & $12.8-177.2$ & 0.069 \\
\hline Glycemia (md/dL) & $\begin{array}{c}145.5 \\
(103-200.5) \\
\end{array}$ & $78-349$ & $\begin{array}{c}157.5 \\
(110.5-258) \\
\end{array}$ & $83-404$ & 0.036 \\
\hline Glycosylated hemoglobin (\%) & $8(6-10.6)$ & $5.5-13.3$ & $8.1(6-10.5)$ & $5.4-14$ & 0.733 \\
\hline $\mathrm{FNT} \alpha(\mathrm{pg} / \mathrm{mL})$ & $\begin{array}{c}35.2 \\
(34.8-35.7) \\
\end{array}$ & $34.8-36.1$ & $\begin{array}{c}31.9 \\
(30.7-33.2) \\
\end{array}$ & $28.8-34.8$ & 0.012 \\
\hline IL1B (pg/mL) & $\begin{array}{c}34.0 \\
(33.8-36.3) \\
\end{array}$ & $33.3-37.3$ & $\begin{array}{c}31 . \\
(30.7-32.8) \\
\end{array}$ & $28.2-34.0$ & 0.012 \\
\hline IL6 (pg/mL) & $4.4(4.3-4.7)$ & $3.9-5.1$ & $\begin{array}{c}3.5 \\
(3.0-3.8) \\
\end{array}$ & $2.8-4.4$ & 0.017 \\
\hline
\end{tabular}

IR: interquartile range, CRP: protein C reactive, SBP: systolic blood pressure, DBP: diastolic blood pressure, HbA1C: glycosylated hemoglobin, DM2: type II diabetes mellitus, HDL: high density lipoprotein, LDL: low density lipoprotein, VLDL: very low density lipoprotein, FNTa: Tumoral Necrosis Factor $\alpha$, IL1B: interleukin 1B, IL6: interleukin 6. 


\section{DISCUSSION}

Currently on the market guava compote contributes on average $21.5 \mathrm{~g}$ of carbohydrates, 87 $\mathrm{Kcal}, 0.2 \mathrm{~g}$ of protein and $0 \mathrm{~g}$ of fat in addition to other ingredients for its conservation. On the contrary, our product has no addition of preservatives, dyes or sweeteners, being a minimally processed food, ideal to be included as a healthy snack in the general population and that conforms to the DASH diet model (Dietary Approaches to Stop Hypertension), proposal as a nutritional strategy to help control hypertension and dyslipidemia; this feeding pattern can help reduce the risk of heart attack and stroke (19). This compote is a new food, which combines two tropical fruits (guayaba and granadilla) and implements the cinnamon spice as a substitute for sugar, in order to enhance the natural flavor of the components. It is considered that it had good acceptance considering that most of the fruit-based products in the current market, such as soft drinks, contain high amounts of sugars (between 15 and $30 \mathrm{~g}$ per serving) and artificial flavors and minimal amounts of fruit (3\%). The sensory analysis of this product was important to ensure adherence to consumption during the intervention phase, as well as to evaluate the general public's perception of a food without adding sugar or sweeteners.

Hydrophilic ORAC antioxidant activity can be attributed to the content of total phenols (14), the lipophilic ORAC could be attributed to the oil content and to the lycopene present in the guava (14, 20), likewise, and its antioxidant activity could also be related to the content of omegas- 3 contributed by the linseed oil and the presence of lycopene (21).

Studies where the effect on cholesterol and triglycerides has been evaluated was generally evaluated after 3 months, in this study it is carried out for a shorter period of time because it was the first time that a product is studied in in this specific population, it does not exist in the market and which we do not know his acceptance and possible adherence to consumption, but with the results in this study; he indicates that we can make an intervention with a larger population and for a longer time.

Related to glycemic control, it should be taken into account that the population studied had initial glycaemia levels higher than the control goals for diabetic patients $(\mathrm{HbA} 1 \mathrm{C}<6.5)$ and perhaps the intervention time was not enough to control the alteration or chronic decompensation, likewise, most patients had a fruit and vegetable intake lower than that recommended by the WHO, equivalent to 5 servings per day (approximately $400 \mathrm{~g}$ ) (4). Therefore, this food could have a better effect if it is accompanied by a dietary control, and could be included as a co-adjuvant of a diet therapy. The objective of this study was not to create a product that replaces hypoglycemic drugs; but it does contribute to the control of glycaemia as a complementary strategy to its treatment, but without an adequate dietary plan it will not have an important effect.

There are some natural foods and beverages that contain phytochemicals that are associated with beneficial effects on human health. Some of these compounds are curcumin, capsaicin, gingerol, catechin, resveratrol, genistein and quercetin, they have reported that they provide an improved state of health to their consumers and have been investigated for their anti-inflammatory effect (22). The beneficial effects on systolic blood pressure of the compote could be due to its action on endothelial function and vasodilation mediated by endothelial cells (21-24). Likewise, the contribution of omega-3, contributed by linseed oil, has been related to the influence it represents on blood coagulation and thrombosis, the profile of plasma lipids, blood pressure, arrhythmia and inflammation (23-25). By incorporating phospholipids in cell membranes, replacing arachidonic acid as the initial substrate for the production of eicosanoid and improving endothelial plasticity (23).

With regard to the inflammatory state, a decrease in the pro-inflammatory cytokines TNF $\alpha$, IL1 $\beta$ and IL6 was found. DM2, like high blood pressure, represents powerful risk factors for the development of CVD. The mechanisms are associated with numerous factors, but recent evidence suggests that the activation of low-grade inflammation could be a trigger for this process (24). IL- 6 and TNF- $\alpha$ are cytokines with metabolic effects; increased circulating levels of IL- 6 alter insulin sensitivity, increase leptin production and lipolysis, and decrease the activity of lipoprotein lipase in adipocytes (26). Our results are consistent with reports made by Vasconcelos et al, (2017), who found that an extract rich in lycopene from red guava showed beneficial effects in inflammation, offering protection against the consequences of oxidative stress by regulating inflammatory 
mediators (decreasing them), and inhibiting the expression of genes involved in inflammation (20).

The cardioprotective effects of polyphenols have been linked especially to their antioxidant properties; because the imbalances between free radical production (oxidative stress) and antioxidant levels in the body constitute one of the important precursors that have been closely linked to the pathogenesis of CVD (27). This is how polyphenolic compounds play a key role in protecting macromolecules from reactive oxygen species (ROS)/nitrogen reactive species (RNS): induced damage, improved antioxidant status, lipid profile and vascular/endothelial function. However, anti-atherosclerotic potential is also attributed to modulate simultaneous signaling and mechanistic pathways (28). It is suggested that polyphenols may regulate cell lipid metabolism; vascular and endothelial function; hemostasis; as well as the platelet function; which represent primary conditions for the formation and development of atherosclerotic plaque. The beneficial effects on systolic blood pressure of the compote may be due to its action on endothelial function and vasodilation mediated by endothelial cells (26).

The daily intake of foods rich in polyphenols, herbs and mixtures, including flavones, anthocyanins, pro-anthocyanins, flavones, flavanones, iso-flavones and flavon-3-lol, improve vascular health, notably reducing hypertension and ECV (29). Phenolic compounds are responsible for the antioxidant capacity of plant extracts (8). Our compote contains an important antioxidant capacity, which can be attributed to the content of phenolic compounds, including cinnamaldehyde (30).

\section{CONCLUSIONS}

The fruit compote complies with the nutritional and sensory characteristics that make it suitable for human consumption and has a contribution of phenolic compounds with antioxidant activity, which makes it ideal to be implemented in therapeutic feeding models. It's a healthy and minimally processed snack option that can be consumed by population with dietary restrictions (like carbohydrates and sugars).

In this research, a food prototype was evaluated as an option to increase the consumption of fruits in the population, highlight the health properties of tropical fruits in the region, and it is also an option to include omega 3 fatty acids of vegetable origin.

The medium-term consumption of guava, passion fruit, cinnamon and flaxseed oil improves systolic blood pressure and blood pressure as well as the inflammatory markers TNF $\alpha$, IL1B and IL6 in eight diabetic and hypertensive patients.

Studies are required in which the potential of the phenolic compounds and lycopene of the pink guava, and the cinnamaldehyde of cinnamon in the primary and secondary prevention of cardiovascular risk are evaluated in the long term (12 weeks).

\section{CONFLICTS OF INTEREST}

The authors declare that there is no conflict of interest with the published results.

\section{ACKNOWLEDGEMENTS}

This project was financed by the sustainability strategy for Research Groups of the School of Nutrition and Dietetics of the University of Antioquia 2018-2020.

\section{AUTHORS' CONTRIBUTIONS}

Camila Franco: preparation of food test, performing of biological assays and analysis of results. Adrián Isaza design of test drink and analysis of clinical data of patients. Gladys Posada: support in anthropometric and nutritional status analysis of subjects. María Elena Maldonado-Celis: design of the study. All authors participated in the writing of the manuscript.

\section{REFERENCES}

1. WHO. Cardiovascular diseases. [Internet]. Descriptive note 2015. Available in: http://www.who.int/mediacentre/factsheets/ fs317/en/

2. WHO. REPORT ON THE WORLD SITUATION of noncommunicable diseases [Internet]. 2014 [cited 2017 Apr 12]. Available in: http://apps.who.int/iris/bitstream/10665/149296/1/ WHO_NMH_NVI_15.1_spa.pdf?ua=1\&ua=1

3. WHO $\mid$ Non-communicable diseases [Internet]. World Health Organization; 2017 [cited 2017 Apr 12]. Available in: http://www. who.int/mediacentre/factsheets/fs355/en

4. Berciano S, Ordová S JM. Promoción de la salud cardiovascular (III): Nutrición y salud cardiovascular. Rev Esp. Cardiol. 2014; 67(9):738-47.

5. Madamanchi NR, Vendrov A, Runge MS. Oxidative Stress and Vascular Disease. Arterioscler Thromb Vasc Biol [Internet]. 2004 Nov 11 [cited 2017 May 13];25(1):29-38. Available from: http:// www.ncbi.nlm.nih.gov/pubmed/15539615 
6. Raggi P, Genest J, Giles JT, Rayner KJ, Dwivedi G, Beanlands RS, et al. Role of inflammation in the pathogenesis of atherosclerosis and therapeutic interventions. Atherosclerosis [Internet]. 2018 Sep 1 [cited 2018 Oct 11];276:98-108. Available from: https:// aplicacionesbiblioteca.udea.edu.co:2062/science/article/pii/ S0021915018312103

7. Anhê FF, Desjardins Y, Pilon G, Dudonné S, Genovese MI, Lajolo FM, et al. Polyphenols and type 2 diabetes: A prospective review. Pharma Nutrition [Internet]. 2013 [cited 2017 Apr 9]; 1(4):105-14. Available in: http://aplicacionesbiblioteca.udea.edu. co:2060/science/article/pii/S2213434413000406

8. Martins N, Barros L, Ferreira ICFR. In vivo antioxidant activity of phenolic compounds: Facts and gaps. Trends Food Sci Technol. 2016; 48:1-12.

9. Rojas-Garbanzo C, Zimmermann BF, Schulze-Kaysers N, Schieber A. Characterization of phenolic and other polar compounds in peel and flesh of pink guava (Psidium guajava $\mathrm{L}$. cv. "Criolla") by ultra-high performance liquid chromatography with diode array and mass spectrometric detection. Food Res Int October 201; 100(3): 445-453. Available in: http://linkinghub. elsevier.com/retrieve/pii/S0963996916306007

10. Isaza, A. Double G Medicinal Smoothie As An Adjunctive To Anti-Hypertensive Medications For Diabetic Patients With Hypertension: Can A Smoothie High In Potassium, Fiber, Vitamin C, Omega 3, Lycopene, Cinnamon And Magnesium Reduce Blood Pressure In Diabetic Patients? An Observational Study. Nutr Perspect [Internet]. 2016 april; 39(2):3642. Available in: https://www.researchgate.net/publication/299595820 MEDICINAL_SMOOTHIE_AS_AN_ADJUVANT_TO ANTI-HYPERTENSIVE MEDICATIONS FOR DIABBETC PATIENTS WITH HYPERTENSION CAN_A_SMOOTHIE_HIGH_IN_POTASSIUM_FIBER_VITAMINA_C_OMEGA_3_LYCOPENE_CINNAMMON ${ }_{-}^{-}$

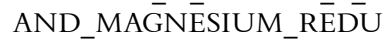

11. Zapata K, Cortes FB, Rojano BA. Polifenoles y Actividad Antioxidante del Fruto de Guayaba Agria (Psidium araca). Inf tecnológica [Internet]. 2013 [cited 2017 May 13]; 24(5):103-12. Available in: http://www.scielo.cl/scielo.php?script=sci arttext\&pid $=$ S0718-07642013000500012\&lng $=$ en\&nrm $=$ iso \&thlng=en

12. Carvajal de Pabón LM, Turbay S, Rojano B, Álvarez LM, Restrepo SL, Álvarez JM, et al. Algunas especies de Passiflora y su capacidad antioxidante. Rev Cubana Plant Med [Internet]. 2011 [cited 2017 Apr 8]; 16(4):354-63. Available in: http://scielo.sld.cu/ scielo.php?script $=$ sci_arttext\&pid $=$ S1028-47962011000400007

13. Hartweg J, Farmer AJ, Holman RR, Neil A. Potential impact of omega-3 treatment on cardiovascular disease in type 2 diabetes. Curr Opin Lipidol [Internet]. 2009 [cited 2017 May 13]; 20(1):30-8. Available in: http://www.ncbi.nlm.nih.gov/ pubmed/19133409

14. Zapata IS, Piedrahita AM, Rojano B. Capacidad atrapadora de radicales oxígeno (ORAC) y fenoles totales de frutas y hortalizas de Colombia. Perspect en Nutr Humana [Internet]. 2014 [cited 2018 Apr 30]; 16(1):25-36. Available in: http://www.scielo.org. co/pdf/penh/v16n1/v16n1a3.pdf

15. AOAC. Official Methods of Analysis of AOAC INTERNATIONAL, [Internet]. 2016 [cited $2018 \mathrm{Apr}$ 30]. Available in: http://www.aoac.org/AOAC_Prod_ Imis/AOAC/PUBS/AOAC_Member/PUBSCF/PUBSA. aspx?hkey $=0$ feb64dc-a23a-4c67-81c9-bf11bceb01d8.

16. Instituto Colombiano de Normas Técnicas y Certificación ICONTEC. Norma técnica Colombiana 285. Frutas procesadas. Mermeladas y jaleas de frutas. ICONTEC: Bogotá DC. 2007.
17. Durán Agüero S, Carrasco Piña E, Araya Pérez M. Alimentación y diabetes. Nutr Hosp [Internet]. 2012 [cited 2018 Apr 30]; 27(4):1031-6. Available in: http://scielo.isciii.es/scielo. php?script=sci_arttext\&pid=S0212-16112012000400010

18. Manjarrés Correa LM, García Carusso M, Calderón Álvarez ML. Tabla Lista de Intercambio de Alimentos. Universidad de Antioquia: Medellín. 1998.

19. Jenkins DJA, Jones PJ, Frohlich J, Lamarche B, Ireland C, Nishi SK, et al. The effect of a dietary portfolio compared to a DASH-type diet on blood pressure. Nutr Metab Cardiovasc Dis [Internet]. 2015; 25(12):1132-9. Available in: http://dx.doi. org/10.1016/j.numecd.2015.08.006

20. Vasconcelos AG, Amorim A das GN, dos Santos RC, Souza JMT, de Souza LKM, Araújo T de SL, et al. Lycopene rich extract from red guava (Psidium guajava L.) displays anti-inflammatory and antioxidant profile by reducing suggestive hallmarks of acute inflammatory response in mice. Food Res Int [Internet]. 2017 [cited 2017 Apr 16]; 99 (2):959-68. Available in: http:// aplicacionesbiblioteca.udea.edu.co:2060/science/article/pii/ S0963996917300273

21. Yan L, Chouw N, Jayaraman K. Flax fibre and its composites - A review. Compos Part B Eng [Internet]. 2014 [cited 2017 Apr 11]; 56:296-317. Available in: http://aplicacionesbiblioteca.udea.edu. co:2060/science/article/pii/S1359836813004228

22. Leiherer A, Mandlein A, Drexel H. Phytochemicals and their impact on adipose tissue inflammation and diabetes. Vascul Pharmacol. 2013; 58(1-2):3-20.

23. Lastra G, Syed S, Kurukulasuriya LR, Manrique C, Sowers JR. Type 2 Diabetes Mellitus and Hypertension: An Update. Endocrinol Metab Clin North Am [Internet]. 2014 [cited 2017 Apr 12]; 43(1):103-22. Available in: http://www.sciencedirect. com/science/article/pii/S0889852913000923

24. Angell SY, De Cock KM, Frieden TR. A public health approach to global management of hypertension. Lancet (London, England) [Internet]. 2015 [cited 2017 May 13]; 385(9970):825-7. Available in: http://www.ncbi.nlm.nih.gov/pubmed/25752181

25. Poudyal H, Panchal SK, Diwan V, Brown L. Omega-3 fatty acids and metabolic syndrome: Effects and emerging mechanisms of action. Prog Lipid Res [Internet]. 2011 [cited 2017 Apr 12]; 50(4):372-87. Available in: http://aplicacionesbiblioteca.udea.edu. co:2060/science/article/pii/S0163782711000324

26. Lukic L, Lalic NM, Rajkovic N, Jotic A, Lalic K, Milicic T, et al. Hypertension in obese type 2 diabetes patients is associated with increases in insulin resistance and IL-6 cytokine levels: Potential targets for an efficient preventive intervention. Int J Environ Res Public Health. 2014; 11(4):3586-98.

27. Ochoa N, Zúñiga LF, Yasno PA, Medina AP, Diaz WJ, López D. La abrumadora evidencia en la patología cardiovascular. Morfolia [Internet]. 2016 January; 8(2):25-37. Available in: http://revistas. unal.edu.co/index.php/morfolia/article/viewFile/58929/57362

28. Vitale M, Vaccaro O, Masulli M, Bonora E, Del Prato S, et al. Polyphenol intake and cardiovascular risk factors in a population with type 2 diabetes: The TOSCA.IT study. Cli Nutr [Internet]. 2016 November 14; 36(6):1686-92. Available in: https://www. ncbi.nlm.nih.gov/pubmed/27890487

29. Hügel HM, Jackson N, May B, Zhang AL, Xue CC. Polyphenol protection and treatment of hypertension. Phytomedicine. 2016; 23(2):220-31.

30. El-Bassossy HM, Fahmy A, Badawy D. Cinnamaldehyde protects from the hypertension associated with diabetes. Food Chem Toxicol [Internet]. 2011 [cited 2017 Apr 10]; 49(11):300712. Available in: http://aplicacionesbiblioteca.udea.edu.co:2060/ science/article/pii/S0278691511003991 